\title{
Green brand awareness and customer purchase intention
}

\author{
Mahama Braimah *
}

University of Ghana Business School, P. O. Box LG 78, Legon-Accra, Ghana

\begin{tabular}{l}
\hline C H R O N I C L E \\
\hline Article history: \\
Received March 25, 2015 \\
Received in revised format \\
August 62015 \\
Accepted August 92015 \\
Available online \\
August 102015 \\
\hline Keywords: \\
Green Brand \\
Awareness \\
Intention \\
Purchase \\
Customer \\
Ghana
\end{tabular}

\begin{abstract}
A B S T R A C T
Green environmental issues have been of topical interest to both researchers and industrialists for some time now. Research on green brands is relatively limited, especially in developing countries, such as Ghana. This study is therefore designed to determine the relationship between customer awareness of green brand issues and their everyday purchase intentions. Using quantitative techniques, the study interviewed 316 people, conveniently selected from various shopping points in Accra. The study found that, the overwhelming majority of respondents though familiar with green issues did not concern themselves with green issues in their everyday purchase decisions. Again, majority of respondents (54\%) familiar with environmental issues confirmed they would not switch from their preferred brands to less fancied brands even if the less fancied brands were more environmentally friendly. It was also confirmed in the study that price, brand name and convenience, performed better than customer concerns for green issues, in influencing respondents' purchase decisions. It would therefore be strategically significance if advocates, policy makers and business leaders reduce the cost of green products to the final consumer, intensive public education campaigns, coupled with strategic brand building efforts to enhance the level of green brand consumption.
\end{abstract}

\section{Introduction}

During the past few decades, the awareness of widespread environmental degradation facing both the current and future generation has been growing. Some experts, according to Kirkpatrick (1990), have suggested that environmentalists have the potential to be the biggest business issue of the 1990s. Kirkpatrick (1990) maintains that this situation has been brought about because of the great deal of attention which has been brought to bear on environmental issues. The number of consumer professions concern for the environment, or what has come to be known as "green orientation", or green marketing issues are growing in number (Donaton \& Fitzgerald, 1992; Grove et al., 1996). Gutfield (1991) noted that, according to one survey, as high as $80 \%$ of American respondents claimed that they are environmentalists. Kirkpatrick (1990) have concluded that it is not surprising therefore that several companies have positioned themselves as organizations that are environmentally responsible in an attempt to capitalize on the public's interest in green marketing issues.

* Corresponding author. Tel: +233 (0) 243753069

E-mail address: mbraimah@ug.edu.gh (M. Braimah) 
Green marketing as a concept has become a popular term in recent years. Organizations have targeted environmentally conscious consumers and at the same time are beginning to respond to the growing possibility of increased and stricter environmental regulations and controls by relevant authorities (Polonsky, 1991; Porter, 1991). Unfortunately however as some writers have observed, the commitment of organizations to the environment is often more evident in their communications and declarations of intentions than in the actual practices (Groves et al., 1996: Fierman, 1991; Garfield, 1991). Despite the fact that academicians, researchers and environmental campaigners have shown a very high level of interest in green brands and green marketing issues, the demand for green products is lower than expected. Experts have argued that a significant gap exist between the concern for environmental issues and the active patronage of environmentally friendly products and services (Mintel, 1995; Crane, 2000). Concerns for the environment and consequently interest in green consumerism appeared to have begun slowing down by the mid-1990s. Mintel's (1995) conducted a follow-up report on an earlier study on the environment, and the results recorded only a small increase in green consumerism since 1990. According to Wong et al. (1996), the frequency as well as the prominence of green claims was also in decline, and green brands and related issues seem to have achieved only limited success.

Gurau and Ranchhod (2005) have however argued that the market for green brands is growing exponentially at global level. Unfortunately, not very many studies have focused attention on how to improve patronage for green brands. Gurau and Ranchhod (2005) maintain that very few studies have paid adequate attention on consumer perspectives and marketing strategies that is capable of moving consumers from just being concern about environmental issues to actually purchasing green brands. This phenomenon is particularly disturbing considering the fact that marketing literature recognizes the significant role consumers' play in influencing organizations and markets (Rivera-Camino, 2007). The situation in Ghana is no different. Research on green marketing issues is limited (Braimah \& Tweneboah-Kodual, 2011). It is critical therefore that these studies be carried out in the country to establish the situation as it is currently in Ghana. Consequently, the study is designed to establish the relationship between green brand awareness and respondent's;

- Current green brand purchase behavior

- Green brand considerations in everyday purchase decision

- Potential of switching from non-green to green brands

The study also seeks to contrast concerns for the environment against selected consumer purchase decision variables.

It is expected therefore that the study would enable companies and environmental campaigners appreciate the level of awareness and patronage of green products in Ghana. It is also anticipated that the study would give insightful pointers to interested parties about the relevant variables that could help enhance consumer demand for green brands. With these insights, companies and green campaigners alike can formulate appropriate strategies to promote the highlighted issues in the study which, it is hoped, would act as a "rallying call" for further research work on green marketing and related issues in Ghana and beyond.

\section{The concept of Green Marketing}

Green marketing received some attention in the 1970s. For instance, the American Marketing Association (AMA) held the first workshop on green marketing issues dubbed "Ecological Marketing" in 1975, the proceedings of which resulted in one of the first books on green marketing entitled "Ecological Marketing" (Henion \& Kinnear, 1976). However, green marketing came into prominence in the late 1980s and early 1990s. Several authors since then have produced and published several other books on the same topic (Coddington, 1993; Ottman, 1993). According to Kassaye (2001), green 
marketing issues are a major trend and of major concern in today's business environment. The increase in consumer awareness about environmental challenges and stricter regulations and control regimes introduced by various governments, especially in the advanced economies brought the demand for green products into sharp focus (Polonsky et al., 1998: Prothero, 1996). According to Peattie and Crane (2005), early academic treatments of green marketing spoke of the rapid increase in green consumerism and this they considered to be heralding a dramatic and inevitable shift in consumption towards green brands (Prothero, 1990; Vandermerwe \& Oliff, 1990). This generated a lot of interest in academic research. Peattie and Crane (2005) contends that a lot of research evidence from reputable research bodies was cited to confirm perceptions that there was a heightened environmental awareness and a growing consumer interest in green products, as well as a willingness to pay for green features (Roper Organization, 1990; Mintel, 1991; Worcester, 1993). Elkington and Hailes, (1988) argued that the highly effective global consumer boycott of CFC-driven aerosols, and the success of publications such as "The Green Consumer Guide" for example were practical evidence of the heightened state of the world about green issues. They contend that there was a burst of corporate activity in the area of green marketing and an upsurge in research and writing amongst academics about green business.

Green marketing has been variously described. According to Polonsky (1994), green marketing incorporates a broad range of activities which includes product modification and changes to the production process. It also involves packaging changes, as well as modifying advertising. Wiener and Doesher (1991) observed that green consumerism is often discussed as a form of 'pro-social' consumer behavior. Green consumerism may be viewed as a specific type of socially conscious or socially responsible consumer behaviours involving an 'environmentalist' perspective. It could therefore be referred to as an 'environmentally concerned consumption' (Antil, 1984; Henion, 1976). In fact, Henion (1976) described green consumers as 'environmentally concerned consumers'. Others see green marketing as the promotion of products with environmental characteristics (Polonsky, 1994). Polonsky (1994) argued that some people see green marketing as the promotion of products with environmental characteristics, and maintains that consumers' usually associate green marketing with terms like recyclable, ozone friendly, and environmentally friendly. Grove et al., (1996) argued that there is a huge array of activities that organizations that choose to practice green marketing can pursue. When the efforts an organization puts in the production, pricing, promotion and distribution of its offerings to the market is done in such a way as not to be harmful to the environment, such efforts can be described as green marketing (Pride and Ferrel, 1993). The development of products and services that conserve energy and other natural resources, offerings that consider consumer sensitivity to cost and their willingness to pay for environmental safety are examples of green marketing practice (Porter 1991). According to Braimah and Tweneboah-Koduah (2011), there is growing concern about green issues in Ghana and notes that the government of Ghana regulates the activities of organizations through the Environmental Protection Agency (EPA). The authors maintain that the EPA is mandated to develop and implement policies and regulations and undertake relevant activities to preserve the environment and also create awareness about the environment and green issues in Ghana. The authors observed that some firms such as Kamsak Ltd and Fan Milk Ghana Ltd are taken up green marketing issues. The office building of the Ministry of Energy for instance, has installed solar panels to provide electricity in an effort to reduce the impact of their electricity consumption on the environment.

\section{Methodology}

The study adopted a quantitative approach in collecting research data through the administration of structured questionnaires in a survey. The questionnaire was developed taking insights from the study objectives and review of relevant literature on green marketing. Data was collected from a sample of 316 respondents. Respondents were conveniently selected. The sample was drawn from several shopping points in Accra, the capital city of Ghana. This was to ensure that the views, opinions and perceptions of persons in the city were fairly represented in the sample. Shopping areas attract a lot of people who are probably there to make purchases or are planning to do same at a later date. These 
shopping points therefore serve as good areas to locate respondents that are able to provide meaningful insights into their views and perceptions of green brands and their buying intentions and everyday buying behaviours. The data collection instrument contained questions that sought to measure customer awareness of green brands and related issues. The questionnaire also contained questions that attempted to measure the relative impact of concerns for the environment and selected purchase decision variables. The study also aimed to determine customer routine purchase behavior with regards to green brands, so the questionnaire included questions that attempted to measure this. Questions that also sought to measure the impact of green brand awareness on consumer purchase intensions were incorporated into the questionnaire. Considering the fact that computers can process large quantities of data in a reliable and fast manner, the computerized data analysis program, SPSS, was used for analysis of the data. Data was interpreted and discussed based on literature on green marketing as well as other existing empirical evidence, giving due attention to the research objectives. Relevant conclusions were drawn from the analyses and discussions of the data, and recommendations made.

\section{Research Findings and Discussion}

\subsection{Demographic Information}

\subsubsection{Gender Distribution of Respondents}

This section presents the results of respondents" demographic information. Respondents for the survey have been profiled according to their gender, age and educational qualifications. Out of the three hundred and sixteen (316) valid questionnaires obtained, one hundred and seventy-three (173) were males whilst one hundred and forty-three (143) were females representing 55\% and $45 \%$ respectively. See Fig. 1(c) below. This result indicates that the study was not skewed to any particular gender and to include views from both genders so as to present a fair demographic result.

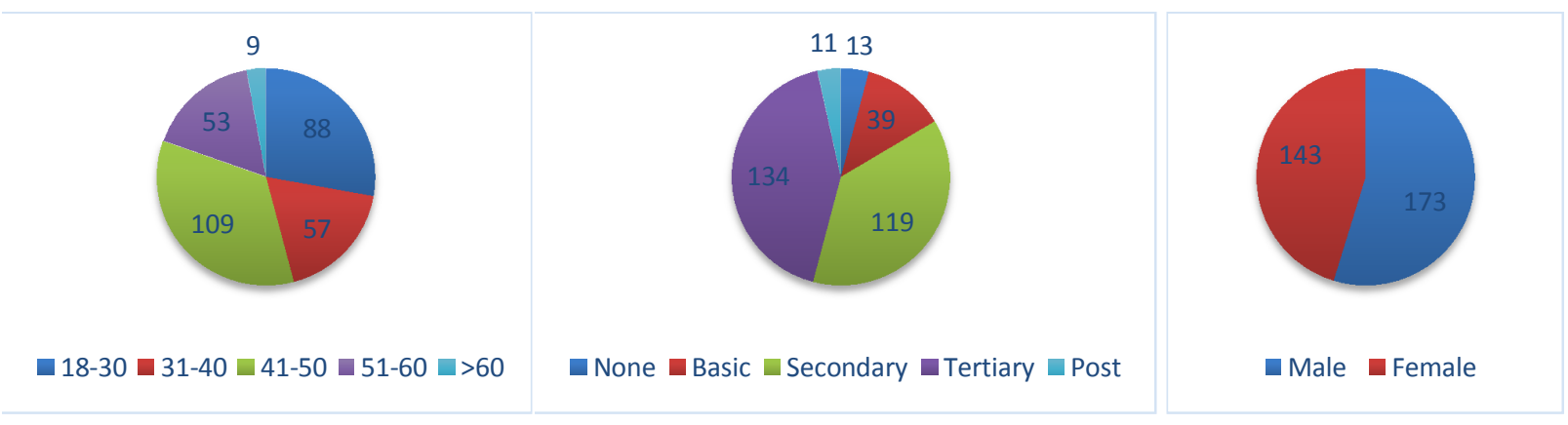

(a) Age

(b) Years of education

(c) Gender

Fig. 1. Personal characteristics of the participants

\subsubsection{Age Categorization of Respondents}

As can be noted from Fig. 1(a) above, with respect to the age of respondents, it was realized that out of the total of 316 , majority of the respondents (109) were within the ages of 41-50 years representing $34 \%$ followed by those within the ages of $18-30$ years accounting for $28 \%$ of the respondents. Those respondents between the ages of $31-40$ and $51-60$ accounted for $18 \%$ and $17 \%$ of the total sample size. Only $3 \%$ of the respondents were 60 years and above.

\subsubsection{Respondents Educational Background}

On the educational qualification of respondents, $96 \%$ had formal education. This implies that the respondents possessed the requisite background to better appreciate green issues. Of those who had 
gone through any form of formal education, almost $38 \%$ had secondary education qualifications, while over $42 \%$ had tertiary qualifications. Over $12 \%$ had secondary education qualifications, while $3.5 \%$ had post graduate education. See Fig. 1(b).

\subsection{Descriptive Statistics}

The cumulative means and standard deviations of the questions are displayed in Table 1. These explain the cumulative extent to which respondents answered yes or no (agreed or disagreed) to these questions. Overall, the highest mean was 1.80 and the lowest was 1.22 .

Table1

Descriptive statistics

\begin{tabular}{cccccc}
\hline & Mean & $\mathrm{t}$ & $\mathrm{df}$ & Sig. (2-tailed) & $\mathrm{N}$ \\
\hline Familiarity with Green Terms & 1.22 & 51.95 & 315 & 0.000 & 316 \\
Ever Purchased Green Brand & 1.28 & 49.79 & 315 & 0.000 & 316 \\
Green Brand Consideration in Purchasing Decision & 1.80 & 79.99 & 315 & 0.000 & 316 \\
Switching Preferred Brand for Green Brand & 1.59 & 53.16 & 315 & 0.000 & 316 \\
\hline
\end{tabular}

\subsection{Green Awareness and Purchase Intensions}

The relationship between green awareness and purchase intentions is presented in table 3 below. The study attempted interacting respondent's familiarity of green brands with various purchasing scenarios. Consequently, the study was interested in interacting respondent familiarity of green brands with whether respondents had ever purchased a green product. Again, the study wanted to determine the relationship between respondents' familiarity with green brands and the consideration they gave to green issues in their everyday routine purchasing decisions. Furthermore, the study attempted to determine whether respondents would switch from buying their favorite brand if they discovered the said preferred brand to be less environmentally friendly than an otherwise less preferred brand. From the study, 244 respondents were familiar with green issues. As shown in Table 2, majority of the respondents who are familiar with green terms had purchased green products before. The relationship between those familiar with green brand terms such as "green marketing", "green products", "environmental marketing" and "environmentally friendly products" and those who are not familiar with such green brand terms and their purchase of green brand was significantly different from zero at $1 \%$. Although most of the respondents were familiar with green terms, the impact on purchasing considerations were significantly different implying that respondents' familiarity did not influence their purchasing decisions. Respondents familiar with green terms exhibited significant switching behavior in arriving at their purchasing decisions. The significance of the cross-tabulations is indicated by the p-values being less than 0.05 .

Table 2

Green Brand Awareness and Purchase Decision

\begin{tabular}{|c|c|c|c|c|c|}
\hline \multicolumn{4}{|c|}{ Familiarity With Green Terms } & \multicolumn{2}{|c|}{ Kendall's tau-b } \\
\hline & & Yes & No & Value & Sig. \\
\hline \multirow[t]{2}{*}{ Ever Purchase Green Brand } & Yes & 206 & 23 & 7.323 & 0.000 \\
\hline & No & 38 & 49 & & \\
\hline \multirow[t]{2}{*}{ Green Brand Consideration in Purchase Decision } & Yes & 58 & 5 & 3.976 & 0.000 \\
\hline & No & 186 & 67 & & \\
\hline \multirow[t]{2}{*}{ Switching from Preferred Brand to Green Brand } & Yes & 113 & 18 & 3.335 & 0.001 \\
\hline & No & 131 & 54 & & \\
\hline
\end{tabular}




\subsubsection{Respondent Purchasing of Green Bands}

Out of 244 respondents who were familiar with green issues, 206 said they have purchased a green brand before, while 38 respondents had never purchased a green product. This implies that about $15.6 \%$ of respondents who are aware of green products did not respond to their familiarity of green issues. 23 respondents who were not familiar with green products confirmed they had bought a green brand before, 49 respondents had not. For the respondents who were not familiar with green issues, their buying of green products can be attributed to chance.

\subsubsection{Green Brand Considerations in Everyday Purchasing Decisions}

Only 58 respondents who were familiar with green brand matters gave any consideration to green issues in their purchase decisions. The overwhelming majority of 186 respondents though familiar with green issues did not concern themselves with these issues in their purchase decisions. This raises the question as to why though respondents were familiar with green issues, these issues did not feature prominently in their buying decisions. 67 of the respondents who were not familiar with green issues confirmed they did not consider environmental issues in their purchase decisions. This is consistent with the fact that once they are unaware of green issues, it could not possible influence their purchase decisions.

\subsubsection{Switching From Preferred Brand to Green Brand}

About 54\% (113) of respondents familiar with environmental issues confirmed that they would not switch from their preferred brands to less fancied brands even if those brands were more environmentally friendly. This scenario again raises the question, why do people who know about green products have a poor attitude to environmental concerns? However, 18 respondents did indicate that they would switch from a preferred brand to a less preferred brand if the less preferred brand is more environmentally friendly. It is interesting to note that about $59 \%$ of respondents confirmed they would not switch brands for more environmentally friendly products even when they become aware of green marketing issues.

\subsection{Most Important Factor Affecting Purchase Decision}

The study was also designed to determine which factors(s) had the most influence on respondents' purchase decisions of the respondents. $73 \%$ of respondents indicated that price was the most critical factor in the considerations of their purchasing decision. Brand name and convenience were the second and third most important factors respectively that influenced respondents' purchased decisions. 21.5\% of respondents chose brand name as the most important factor influencing their purchase decision, while about $4.7 \%$ said convenience was the key factor. Interestingly, only 1 respondent indicated that environmental issues influenced his or her purchased decision. The results are presented in Table 3.

Table 3

Relative Importance of Various Factors in Purchase Decisions

\begin{tabular}{ccc}
\hline & Frequency & Percent \\
\hline Environmental & 1 & 0.316 \\
Price & 232 & 73.418 \\
Brand Name & 68 & 21.519 \\
Convenience & 15 & 4.747 \\
\hline
\end{tabular}

\section{Conclusions}

The production and consumption of environmentally friendly products has been of major concern over the pass decades to green environmental campaigners. However, research has demonstrated that the level of patronage of green brands though showed promise at the beginning, has fallen short of anticipated levels. It is evident from this study that the situation in Ghana is not different. Over 20\% of sampled respondents were not familiar with green marketing issues, and this situation is worrying considering the fact that the planet is reported to be experiencing climate warming. Efforts must be 
made to enhance awareness of the production and consumption of environmentally friendly products and services. In the study, a majority of sampled respondents are familiar with green marketing issues. This majority constituted over $77 \%$ of respondents. Even with this category of respondents, the awareness of green environmental issues did not directly influence their everyday purchase decision. This situation raises several questions that demands answers. For instance, it is that people who are aware of green environmental issues do not appreciate it or does not believe what they hear? Again, is it possible that people who are aware of environmental issues appreciate and/or believe what they hear, but there are other needs that are clearly more pressing and relevant to these individuals that override concerns for the environment; and what are those factors? An attempt was made in this study to determine some factors that might be considered by respondents as more relevant that environmental concerns. Respondents were asked to contrast their concern for green issues against "brand name", "convenience" and "price". Price was clearly picked as the most relevant factor in influencing respondents purchase decisions. Sampled respondents' concern for the environment was the least factor that affected their purchased decisions. Both "brand name" and "convenience" were considered ahead of environment issues.

\section{Implication for Policy and Business}

Price emerged in this study as more credible determinant of customer purchase decision than environmental considerations. Though price might not be that important in more prosperous economies, in developing countries such as Ghana, price remains a key variable in purchase decision making. It would therefore be of strategic significance if policy makers and business leaders can reduce the cost of green products to the final consumer. Intensive public education campaigns by public institutions coupled with strategic brand building effort by business houses could improve the levels of awareness and consumption of green brands.

\section{Direction for Future Research}

The study focused on awareness of green brand issues on purchase intentions. The study did not consider the potential impact of such demographic variable as age, gender and educational background of respondents on the acceptance and consumption of green products. Future studies could investigate whether age, gender, education and occupation has any bearing on green brand consumption. It would also be interesting for further research to contrast respondents concerns for green issues against a broader scope of variables to determine which variables are considered more important that environmental concerns to the respondent, especially in a developing country context. Another interesting area of research on green issues in Ghana is to establish whether companies producing products and services that can be harmful to the environment are making the needed efforts at addressing green concerns? The output of these studies would help policy makers and business leaders develop policies, products and services that address environmental issues from the side of the producers and also appeal to the generality of the population. The response of companies to green marketing issues is therefore another area that is worth investigating.

\section{Acknowledgement}

The author wishes to acknowledge the University of Ghana Business School (UGBS) for financially supporting this study. The UGBS provided funds for the entire study. This study would not have been possible without the support of UGBS.

\section{References}

Antil, J. H. (1984). Socially responsible consumers: Profile and implications for public policy. Journal of Macromarketing, 4 (Fall), 18-39. 
Braimah, M. \& Tweneboah-Koduah, E.Y. (2011). An exploratory study of the impact of green brand awareness on consumer purchase decision in Ghana. Journal of Marketing Development and Competitiveness, 5(7), 11-18.

Coddington, W. (1993). Environmental Marketing: Positive Strategies for Reaching the Green Consumer. New York: McGraw-Hill Inc.

Crane, A. (2000). Facing the backlash: Green marketing and strategic re-orientation in the 1990s. Journal of Strategy Marketing, 8(3), 277- 296.

Donaton, S., \& Fitzgerald, K. (1992). Polls show ecological concern is strong. Advertising Age, 63(3), 19-23.

Elkington, J. \& Hailes, J. (1988). The Green Consumer Guide. London: Victor Gollanz.

Fierman, J. (1991). The big muddle in green marketing. Fortune,123(3), 91-101.

Garfield, J. (1991). Beware green overkill. Advertising Age, 62(5), 26.

Grove, S.J., Fisk, R.P., Pickett, G.M. \& Kangun, N. (1996). Going green in the service sector: Social responsibility issues, implications and implementation. European Journal of Marketing, 30(5), 5666.

Gurau, C. \& Ranchhod, A. (2005). International green marketing: A comparative study of British and Romanian firms. International Marketing Review, 22(5), 547-561.

Gutfield, R. (1991). Eight of ten Americans are environmental, at least they say so. Wall Street Journal, 2 September, Section A, 1.

Henion, K.E. \& Kinnear, T.C. (1976). Measuring the effect of ecological information and social class on selected product choice criteria importance ratings. Ecological Marketing, Chicago: American Marketing Association, 145-156.

Kassaye, W.W. (2001). Green dilemma. Marketing Intelligence \& Planning, 19(6), 444-455.

Kirkpatrick, D. (1990). Environmentalism, the new crusade. Fortune, 21, (12 February), 44-52.

Mintel (1991). The Green Consumer Report. London: Mintel.

Mintel (1995). The Second Green Consumer Report. London: Mintel.

Ottman, J.A. (1993). Green Marketing: Challenges \& Opportunities, NTC Business Books, Chicago, IL.

Peattie, K. \& Crane, A. (2005). Green marketing: Legend, myth, farce or prophesy?. Qualitative Market Research: An International Journal, 8(4), 357-370.

Polonsky, M.J. (1991). Australia sets guidelines for green marketing. Marketing News, 25(21), 6-18

Polonsky, M.J. (1994). Green marketing regulation in the USA and Australia: The Australian checklist. Greener Management International, 5, 44-53.

Polonsky, M.J., Roserberger, P.J. III \& Ottman, J. (1998). Developing green product: Learning from stakeholders. Asia Pacific Journal of Marketing and Logistics, 10(1), 22-43.

Porter, M.E. (1991). American green strategy. Scientific America, 264(April), 168.

Pride, W.M. \& Ferrel, O.C. (1993). Marketing, Boston: Houghton Mifflin.

Prothero, A. (1990). Green consumerism and the societal marketing concept: Marketing strategies for the 1990s. Journal of Marketing Management, 6(2), 87-103.

Prothero, A. (1996). Environmental decision making: Research issues in the cosmetics and toiletries industry. Making Intelligence and Planning, 14(2), 19-25.

Rivera-Camino, J. (2007). Re-evaluating green marketing strategy: A stakeholder perspective. European Journal of Marketing, 41(11/12), 1328-1358.

Roper Organization (1990). The Environment: Public attitudes and individual behaviour. New York: Roper Organization and SC Johnson \& Son.

Vandermerwe, S. \& Oliff, M. (1990). Customers drive corporations green. Long Range Planning, 23(6), 10-16.

Wiener, J.L. \& Doescher, T.A. (1991). A framework for promoting cooperation. Journal of Marketing, 55(April), 38-47.

Wong, V., Turner, W. \& Stoneman, P. (1996). Marketing strategies and market prospects for environmentally-friendly consumer products. British Journal of Management, 7(3), 263-281.

Worcester, R. (1993). Public and Elite Attitudes to Environmental Issues, MORI, London. 